\title{
E-TOURISM, AS DISPLAY OF DOMINANT CRITERION OF MODERN TOURISM-OPERATING: RELEVANT PROVISIONS, TOOLS, USE
}

\begin{abstract}
Modern world tourism has become an information-dependent industry. At the moment, there is a rapid trend in the transformation of the society into developed information society. Therefore, the logical goal of the work is to research innovative trends in the development of intelligent web services to create and formulate recommendations for the further development of the tourism industry. The methodological part of the article is based on the use of modern information technologies in the field of tourism, focused on the basis of ePlatforms of the tourism industry. As a result, in many tourist enterprises of the 21 st century, significant adaptations must be made to remain solvent and profitable. The effectiveness of the research can be traced to the bright trend of transformation in the world, and in particular in Ukraine, the traditional tourism industry, the e-tourism industry. Scientific novelty consists of conceptual improvement of the manifestation of the dominant criterion of modern tourism operating and its derivatives: e-tourism can be defined as the analysis, development, formation, implementation and application of IT solutions and e-commerce in the world and national tourism industry. Practical significance of the research results is relevant: the need for perfect managers able to manage the tourism business, integrate information and communication technologies (ICT) within the company, to anticipate and promote ICT developments to better meet the needs of the tourism business.

The article is written in the form of an analytical review of innovative IT in the field of tourism. The authors present a number of important characteristics of research.
\end{abstract}

Keywords: e-tourism, information and communication technologies, information base of tourism, audio, audio guide.

Тетяна Ткаченко, Леся Ковальська. Е-TOURISM ЯК ПРОЯВ ДОМІНУЮЧОГО КРИТЕРІЮ СУЧАСНОГО ТУРОПЕРЕЙТИНГУ: АКТУАЛЬНІ ПОЛОЖЕННЯ, ІНСТРУМЕНТИ, ВИКОРИСТАННЯ

В основу дослідження покладено концептуальне удосконалення прояву домінуючого критерію сучасного туроперейтингу та його похідних. На основі розрахунків встановлена яскрава тенденція трансформації у світі та Україні, традиційної туристичної індустрії, індустрією електронного туризму (e-tourism). Проаналізовано потребу в універсальних керівниках, здатних забезпечити управління туристичного бізнесу, інтеграції інформаційних і комунікаційних технологій в рамках компанії, передбачати і просувати розробки для більш повного задоволення потреб туристичного бізнесу.

Ключові слова: e-tourism, інформаційні й комунікаційні технології, базис інформатизації туризму, аудіоінформація, аудіогід.

Татьяна Ткаченко, Леся Ковальская. Е-TOURISM КАК ПРОЯВЛЕНИЕ ДОМИНИРУЮЩЕГО КРИТЕРИЯ СОВРЕМЕННОГО ТУРОПЕРЕЙТИНГА: АКТУЛЬНЫЕ ПОЛОЖЕНИЯ, ИНСТРУМЕНТЫ, ИСПОЛЬЗОВАНИЕ

В основу исследования положено концептуальное совершенствования проявления доминирующего критерия современного туроперейтинга и его производных. Установлена яркая тенденция трансформации традиционной туристической индустрии, индустрией электронного туризма (e-tourism). Проанализирована потребность в универсальных руководителях, способных обеспечить управление туристического бизнеса, интеграции информационных и коммуникационных технологий в рамках компании, продвигать разработки для полного удовлетворения потребностей туристического бизнеса.

Ключевые слова: e-tourism, информационные и коммуникационные технологии, базис информатизации туризма, аудиоматериалы, аудиогид.

Formulation of the problem. In the context of the rapid and rapid development of world tourism, the question of Ukraine's role in the world market of tourist services is naturally raised. It should be noted that objectively the country has all the prerequisites and prospects for the positive development of domestic and foreign tourism. Today, the tendency of total transformation of society into the information society is traced, which involves every sphere of everyday life with a tangent. For integration into postmodern space, world tourism also introduces new tools and mechanisms of operation: an online version of the electronic expansion.

Analysis of recent research and publication. While writing of the article, a large number of scientific and educational-methodical works was worked out and used. Given the rapid evolution of technical progress every day, the theme of e-tourism as a manifestation of the dominant criteria of modern tour operators and the implementation of information technology in tourism is very relevant and requires a more detailed study, today many questions remain without a clear answer and also there is a lack of scholars and specialists in the field of tourism. The basis of this work is the works of famous scientists, both in Ukraine and abroad, the scientists: Novikova V.S, Izotova M., Matyukhina Y., Kozlitina N.E. and Velytin N.A.

Selection of previously unsettled parts of general problem. The public use of the Internet has created a number of conditions that have changed the process of exchange - both in useful and in a loss for a modern tourist enterprise. As a result, many tourist enterprises of the XXI century had to make significant adaptations in order to remain solvent and cost-effective. 
E-Tourism can be defined as the analysis, development, implementation and application of IT solutions and ecommerce in the tourism industry; as well as the analysis of relevant economic processes, market structures and customer relationship management, therefore, accordingly, the need for universal managers able to provide management and management of the tourism business, the integration of information and communication technologies (ICT) within the company, to anticipate and promote the development ICT for better understanding the needs of the tourism business.

The purpose of the article is to research a number of innovative trends in the development of intellectual web services to create and formulate recommendations for the further development of the tourism industry, as well as highlight a number of topical issues. The methodological part of the article is based on the use of modern information technologies eRlatforms in the field of tourism, which is focused on the information basis of the tourism industry.

Presenting main material. The modern world market puts new demands, rules and trends in order to get productive work. So, for today's tourism specialist there is a primary knowledge of the effectiveness of upto-date Internet marketing tools and peculiarities of their use, trends in design and social networks, as well as innovative automation of the national and world tourist segments. A successful example of a tourism business in the conditions of digitalization, where communication with tourists takes place on a virtual level and in the fast online current, which makes them permanent clients for a long time.

During the Internet conference, Aron Mayberg, chairman of the UIA's supervisory board, noted that on airplanes of the UIA, in the beginning of 2018, an onboard Internet will appear. "International airlines of Ukraine" will start receiving long-range aircraft Boeing 777 , on board, passengers will be able to use the onboard Internet, in addition, aircraft will also have an entertainment system, information terminal with a fixed in each chair both in the business class and the economy class. Under the existing plans of the UIA, it expects to receive four Boeing 777, which will be operated in parallel with the Boeing 767 flies to this day, which will be withdrawn from the fleet since 2019.

E-tourism is an online service that is a platform for direct sales, easy payment for end-user services, business development between manufacturers, service providers, TO, TA and intermediaries [1].

The information basis of tourism lies in tourism technologies, they are also called automation of hospitality - the use of information technology (IT) or information and communication technologies (ICTs) in the field of travel, tourism and hospitality. Since travel involves only travel, travel technology was originally linked to the computer reservation system of airlines, but in our time it is used more and more inclusive, joining the broad sector of the tourism industry, as well as its subgroups of the hospitality industry, those are, transfer, excursions, meals, etc.

The online sales software provides access to up-todate information on air and hotel reservations, and also provides a quick update of the database, but in practice, the following changes are not always calculated, so, Join UP! announced a new pre-booking service, which allows you to fix its value during the 24-hour period for the SPO reservation service when booking a tour. If, for a day TA does not transfer the application to the active armor status, the previous reservation will be automatically canceled without penalty. Thus, the tourist will have an additional time to make a decision, but there are nuances: the service applies exclusively to package tours with a guaranteed flight to Egypt, Turkey, Montenegro, Sri Lanka, Georgia.

In addition to leave must remain at least five days, and on the flight - at least ten vacancies. Of course, such a scheme in the Ukrainian market is not news, but the fact that now a big player like Join UP has joined the news is definitely a positive one. The international global booking systems for tourist services are Galileo, Saber, Worldspan and Amadeus. Thus, according to Alexei Muromtsev, General Director of «Amadeus Ukraine», Amadeus is the supplier of IT solutions for the global tourism and travel industry, the largest operator of information requests (transactions) of the industry. It has been operating in more than 195 countries.

The Amadeus system gives tour agents access to the resources of many of our tour operators. The largest volume of passenger seats on regular flights of airlines around the world is conducted through the Amadeus system. The system is used by more than 90,000 travel agencies and 4,500 corporate clients from all over the world. The company has centers in Madrid (central office), Nice (development and development center) and Erdinge (operating center), as well as 71 commercial offices. In 2016 more than 2.5 million national tourists benefited from TA services, which exceeded the indicator of last year by $25 \%$ and 35 thousand foreign tourists $(+133 \%)$.

For most of them $(85 \%)$ the main purpose of travel was tourism, not business trips. Based on statistical data, it was concluded that the total revenue from provision of tourist services in the past year amounted to 11.94 billion UAH. (amount without VAT, excise tax and other obligatory payments). As the director of the company says right now, in connection with the provision of our country's visa-free regime, players in the Ukrainian market need to rethink their strategies and be under the grip of new realities, but the CEO of Amadeus Ukraine is confident that the whole industry will not just survive "Earthquake", but also increase its income. The market of Ukrainian manufacturers of online booking systems is still under construction. Among several domestic software developments is Titbit, Turtess Online [2].

The spectrum of applications is expanding in fact more and more, from the usual reservation of traveltechnology transformed into E-tourism, that is, in electronic tourism in the form of technology virtual tours. From the point of view of marketing, the virtual tour is an effective visualization tool that allows the potential consumer to display his product or service, creating an illusion of presence at the viewing site, thus creating unique bright visual images [3]. 
For example, the Musée du Louvre in Paris developed virtual content in order to carry out a 3D tour where the user can move around the stairs to the palace and to each exhibit, interior and historical references, audio information is prepared on an audio guide in English and French. Another variant of the online worlds, which has recently been circulated, is the so-called "Second Life" - a three-dimensional virtual world with elements of a social network that has more than 1 million active users. Second Life also has a virtual currency called Linden Dollar (L \$), which can be obtained by exchanging real money; there is also provided a reverse conversion, which creates an opportunity to organize in the Second Life completely real business schemes [4].

"Second Life" provides significant opportunities for virtual tourism. For example, the online version of the Paris Louvre, the Dresden Picture Gallery, and other museums in the United States and Western Europe, many capitals and large cities in the world. In this case, the virtual tour allows you to get acquainted with the objects of art stored in the world's museums and their buildings in all details (for example, the American $\mathrm{Mu}-$ seum of Old Masters Picture Galleries is displayed with incredible credibility - besides 750 art objects, you can see, even modeling on the ceiling [5].

Now the guide can be a GPS-guide, and the guide can be audio guide, podcast or I-Tour, for example, audio guides in the city. Currently, almost all major museums in the world provide an opportunity to make an interactive tour of art masterpieces. For example, the Parisian Museum of the Louvre (Musée du Louvre) or the Museum of Modern Art (MoMA) in New York, the National Gallery of London and many other well-known museums provide audio guides and reproductions of paintings or other exhibits on the site for free, in several languages of the world, and also develop their own applications for smartphones.

CultureEspace is a French cultural space that combines dozens of French museums, villas and other tourist destinations, which in turn, for the sake of the convenience of tourists, has developed its own application for each facility, for Villa Ephrussi de Rothschild) in San Juan Cap Ferrara on the Apple Store and on Google Play, you can download the original app, which contains, in addition to audio and text information, a lexical dictionary of rare words used during the tour, as well as a plan, route tips and main news for posters of the west . Thus, museums and galleries try to make art more open to society.

One of the important IT developments is the $\mathrm{QR}$ code - a matrix code (two-dimensional barcode) developed and presented by the Japanese company DensoWave in 1994. The main advantage of QR-code is the easy recognition of scanning equipment and a sufficiently large number of characters. The QR code is popular both in tourism for airline or railway tickets and worldwide tourist destinations: while in the city of Lion, a business association called "Tourist Movement of Lviv" has placed QR-codes for about 80 tourist objects.
This makes it easy for tourists to navigate the city without even knowing the Ukrainian language, because the QR-codes are set in several languages of the world. Many museums go on excursion service with QR codes: The Musée Matisse de Nice, a truly innovative innovation that promotes the rapid involvement of tourists in exploring, learning and discovering tourist destinations famous all over the world.

The Internet has a powerful impact on hospitality and tourism. Online tourism is becoming one of the most effective vertical markets, where $64 \%$ of deals are made through the Internet, while in other industries this figure ranges from $30 \%$ to $40 \%$.

A tangible innovation is the complete transition of TO and TA exclusively to mobile or Internet communications. A striking example is the Kyiv Tourist Firm "I will fly, where I want", which distributes its product directly to the Viber network for its clients, or tours with home delivery to the tourist, which makes the offers come as fast as possible and close to the consumer.

This phenomenon confirms that it is the perfect finished product for online sales, but has online competition. The reason for this was a sharp decline in the domestic currency rate in the Coral Travel Corps - up to UAH 26.46. for 1 dollar and up to 30.37 for 1 euro, which is considerably lower than that of other TO market (for comparison: at Anex Tour, for example, the domestic rate according to the first half of June was UAH 26.87 per 1 dollar and up to 30.72 per 1 euro, Join UP !, Pegas Touristik, TUI, Travel Professional Group, TEZ Tour and Natalie Tours - respectively 26.92 / 30.77, Mouzenidis Travel - 26.70 / 30.40, ALF - 26.94 / 30.77, Accord - 27.80 / 30.00). In some other TO courses, the course is close to Coral Travel, but does not compare shipments abroad. It would seem that the difference is small, and when you select a tour from the budget and the middle segment, the tourist does not win much, but TA note that here come into force not so much economic as psychological factors.

Conclusion. Thus, the ongoing evolution of information technology has had a significant impact on the operation of travel agencies. Widespread public use of the Internet has created a number of conditions that have changed the process of exchange - both in useful and in a disadvantage for a modern tourist enterprise: as a result, many enterprises of the tourist industry of the XXI century of the world, and Ukraine in particular, will have to make significant adaptation reforms, to remain solvent and cost effective.

E-Tourism can be defined as the analysis, development, implementation and application of IT solutions and e-commerce in the tourism industry; as well as analysis of relevant economic processes and market structures and customer relationship management.

At present, the need for universal managers capable of managing tourism business, integrating information and communication technologies (ICTs) within the company, and anticipating and promoting the development of ICTs to better meet the needs of the tourism business. 


\section{Список використаних джерел:}

1. Ткаченко T.I. Національний туроперейтинг як різнопланово-секторальна система України / T.I. Ткаченко // Актуальные научные исследования в современном мире: материалы XXII Междунар. научн. конф., 26-27 февр. 2017 г.: сб. науч. тр. - Переяслав-Хмельницкий, 2017. - Вып. 2 (22), ч. 8. - С. 12-17. - [Електронний pecypc] - Режим доступу: https://elibrary.ru/item.asp?id=28786466/ (дата звернення: 15.09.2017). - Назва 3 екрану.

2. Ткаченко Т.І. Національний туристський продукт: образ, імідж, бренд (рекреаційно-туристський аспект) / Т. Ткаченко, Т. Кляпко // Географія та туризм: наук. зб. - Київ, 2014. - Вип. 27. - С. 97-105.

3. Ткаченко T.I. Сучасна модель створення національного туристичного продукту «Буки: розвиток через туризм»: практичний аспект / T.I. Ткаченко // Перспективи розвитку туризму в Україні та світі: управління, технології, моделі: колект. монографія / за наук. ред. проф. Матвійчук Л.Ю. - 3-тє вид. - Луцьк: IВВ Луцького НТУ, 2017. - С. 23-44.

4. Навчання у віртуальному світі [Електронний ресурс]. - Режим доступу: http://www.secondlife.com.

5. Віртуальний тур [Електронний ресурс]. - Режим доступу: http://www.denso-wave.com/en/index.html.

\section{References:}

1. Tkachenko, T.I. (2017). Natsionalniy turopereytynh yak riznoplanovo-sektoralna systema Ukrainy [National TourOperator a diverse system of Ukraine-sectoral]. Aktualnye nauchnye issledovaniya v sovremennom mire: materialy XXII Mezhdunar. nauchn. konf., 26-27 fevr. 2017 g.: sb. nauch. tr. Pereyaslav-Khmelnitskiy, 2 (22), 8, 1217. Available at: https://elibrary.ru/item.asp?id=28786466/.

2. Tkachenko, T. Klyapko, T. (2014). Natsionalnyi turystskyi produkt: obraz, imidzh, brend (rekreatsiyno-turystskyi aspekt) [National tourism product, image, brand (recreational and tourism aspect)]. Geografiya ta turyzm. Kyiv, 27, 97-105.

3. Tkachenko, T. (2017). Suchasna model stvorennya natsionalnoho turystychnoho produktu «Buky: rozvytok cherez turyzm»: praktychnyi aspekt [Modern model of creating a national tourism product "Buki: development through tourism": Practical]. Perspektyvy rozvytku turyzmu v Ukrayini ta sviti: upravlinnya, tekhnologii, modeli: kolekt. monografiya / za nauk. red. prof. Matviychuk L.Yu. Lutsk, Ukraine: Lutsk IVV NTU, 23-44.

4. Navchannya u virtualnomu sviti [Learning in the virtual world]. Available at: http://www.secondlife.com.

5. Virtualnyi tur [Virtual tour]. Available at: http://www.denso-wave.com/en/index.html.

Надійшла до редколегї 20.11.2017 p. 